\title{
Personal Philosophy and Personnel Achievement: Belief in Free Will Predicts Better Job Performance
}

Social Psychological and

Personality Science

I(I) 43-50

(C) The Author(s) 2010

Reprints and permission: http://www. sagepub.com/journalsPermissions.nav DOI: I0.1 I77//94855060935।600 http://spps.sagepub.com

@SAGE

\author{
Tyler F. Stillman', Roy F. Baumeister', Kathleen D. Vohs², Nathaniel M. Lambert', \\ Frank D. Fincham', and Lauren E. Brewer'
}

\begin{abstract}
Do philosophic views affect job performance? The authors found that possessing a belief in free will predicted better career attitudes and actual job performance. The effect of free will beliefs on job performance indicators were over and above wellestablished predictors such as conscientiousness, locus of control, and Protestant work ethic. In Study I, stronger belief in free will corresponded to more positive attitudes about expected career success. In Study 2, job performance was evaluated objectively and independently by a supervisor. Results indicated that employees who espoused free will beliefs were given better work performance evaluations than those who disbelieve in free will, presumably because belief in free will facilitates exerting control over one's actions.
\end{abstract}

\section{Keywords}

free will, philosophy, job performance, locus of control, Protestant work ethic, motivation, management science

The extent to which people exercise volition has been the subject of debate for centuries, with some thinkers favoring determinism (e.g., Hobbes, Spinoza) and others (e.g., Milton, Sartre) asserting that people have the power to choose their behaviors and thoughts. This is not just a debate among scholars. Laypersons also differ in their personal philosophies; some view their own behavior as a series of chosen acts, whereas others believe themselves to be at the mercy of childhood experiences, neurochemistry, genetics, or fate. The present investigation does not seek to resolve that debate but to capitalize on those differences of opinion. Specifically, we test the hypothesis that a belief in free will contributes to effective performance in the workplace.

The notion of free will became important in Western thought in the context debates about scientific causality, moral responsibility, and related topics. These may seem like academic issues far removed from everyday behavior. However, an influential investigation by Vohs and Schooler (2008) showed that variations in belief in free will contributed to changes in behavior among students taking a test for money. Specifically, students induced to disbelieve in free will were more likely to cheat on the test, effectively stealing money in the process, as compared to students who were allowed or encouraged to believe in free will. Subsequent work using similar procedures has shown that manipulated disbelief in free will contributes to increases in aggression and decreases in helpful, prosocial inclinations (Baumeister, Masicampo, \& DeWall, 2009).
Why should a personal opinion about free will change practical behavior? The essence of the idea of free will is that there is more than one behavior that is possible for a particular person in his or her circumstances (e.g., Kane, 2002). Determinism, which is often opposed to free will (although some so-called compatibilist theories have attempted to reconcile the two), asserts that causal processes make every event inevitable, so that the future is as unalterable as the past. In that view, belief in multiple possibilities (and hence in choice among them) is an illusion. To laypersons, determinism is thus closely related to fatalism, or the belief that it does not matter what you do because you cannot change what is about to happen. Such a belief may undermine the motivation to exert oneself.

Exertion has come to figure prominently in recent theories of agency and the self's executive function. Self-control and decision making appear to deplete an energy resource, indeed one linked to glucose, which is the body's and brain's basic fuel supply (Baumeister, Vohs, \& Tice, 2007; Gailliot et al., 2007; Vohs et al., 2008). Thus, in an important and literal sense, it

\footnotetext{
' Florida State University, Tallahassee, FL, USA

${ }^{2}$ University of Minnesota, Minneapolis, MN, USA

\section{Corresponding Author:}

Tyler F. Stillman, Florida State University, Department of Psychology, I 107 W. Call St., Tallahassee, FL 32306-430I,

Email: stillman@psy.fsu.edu
} 
takes less energy to yield to lazy, selfish impulses and other temptations than to make oneself overcome such temptations.

Work, almost by definition, consists of behavior done for extrinsic rewards and in response to external demands. The activities involved in work rarely consist of indulging lazy or selfish inclinations; on the contrary, such tendencies must usually be held in check for workers to effectively discharge their duties. Effective work therefore often depends on selfregulation (e.g., control over sexual urges, selfishness, hostility, and laziness) and may invoke the psychological and even biological costs that self-regulation carries.

Thus, work requires a willingness to exert the will, whereas disbelief in free will may reduce that motivation. Our main hypothesis was therefore that disbelief in free will would detract from workplace performance, whereas belief in free will would be conducive to performing well. The goals of the present investigation, however, go beyond merely establishing that variation in beliefs about free will predict workplace performance. Instead, we sought to establish a specific, distinctive contribution of these beliefs. To do that, we assessed several potentially related variables to establish whether the hypothesized effects of free will were independent of them. Each is discussed in turn.

First, locus of control (more precisely termed locus of control of reinforcement) is an individual-difference construct based on perceptions of the effects of one's behavior (Rotter, 1966). People with an internal locus of control (internals) believe that their behavior affects the likelihood of receiving reinforcement, whereas those with an external locus of control (externals) believe reinforcement is independent of their behavior. According to expectancy theory (Vroom, 1964), perceiving a relatively strong relationship between efforts and outcomes causes greater efforts, so one would expect internals to put forth more effort toward their job than externals. A qualitative review of the literature concluded that internals have favorable outcomes in several work-related variables compared to externals (Spector, 1982). A quantitative meta-analysis found greater internal locus of control was related to better job performance and higher job satisfaction (Judge \& Bono, 2001). A more recent quantitative meta-analysis found that internal locus of control predicted many favorable job-related outcomes (Thomas, Sorensen, \& Eby, 2006). Locus of control is also an important part of a trait termed core self-evaluation (the other parts being self-esteem, self-efficacy, and emotional stability), and core self-evaluation predicts better job performance (Judge, 2009; Judge \& Hurst, 2007).

Both those with an internal locus of control and those who believe in free will perceive a stronger relationship between the individual and the outcome than do externals and determinists. In other words, externals and determinists view the individual as further removed from the outcome than do internals or those who believe in free will. A deterministic view of inevitable outcomes suggests that efforts do not matter because the outcome - good or bad-is predetermined. Thus, one can predict that determinists, like externals, would not put forth the effort required to perform one's job well.
Second, belief in the Protestant work ethic has conceptual overlap with free will. Early Protestants, especially Calvinists, believed that occupational success was a sign of divine favor and therefore a promising predictor of being destined for salvation in heaven (Weber, 1905). In practice, having a strong Protestant work ethic entails a desire to be independent, delay gratification, and achieve success (McClelland, 1961). Those who espouse a Protestant work ethic are demonstrably more industrious and intrinsically motivated than those who do not (Furnham, 1990), which supports the general claim that differences in lay philosophies have implications for job performance. Thus, both the belief in free will and the belief in the Protestant ethic encourage people to exert themselves to succeed in the workplace.

All of the so-called Big Five dimensions of personality have been shown to predict job performance, though only one of them (conscientiousness) produces sizeable correlations (for reviews, see Barrick \& Mount, 1991; Tett, Jackson, \& Rothstein, 1991). Conscientiousness is most closely related to self-control and the self's executive function, which is highly relevant insofar as our theory emphasizes that belief in free will benefits workplace performance by means of motivating exertions of self-control and executive function.

One heavily researched topic in the job performance literature relates to cognitive ability. Although specific cognitive aptitudes (e.g., verbal or spatial) generally are not good predictors of job performance (e.g., Brown, Le, \& Schmidt, 2006; Hunter, 1983; but see Mount, Oh, \& Burns, 2008), general mental ability is a reliable predictor of job outcomes (for a review, see Schmidt \& Hunter, 2004). It was possible that cognitive ability would be related to belief in free will, and so we sought to establish that any effects of belief in free will remain significant after controlling for cognitive ability.

Personal vitality was another possible confound. Our reasoning emphasized that belief in free will would contribute to willingness to exert energy for self-control and executive function to facilitate workplace performance. The Vitality Scale developed by Ryan and Frederick (1997) assesses individual differences in feelings of energy. That scale was included (in Study 2) to determine whether belief in free will would affect workplace performance independent of differences in feelings of vitality and energy.

Last, we acknowledge the possibility that people who believe in free will may have a more positive, optimistic outlook on life and hence may simply feel better, which could in turn have an impact on job performance. We therefore measured global life satisfaction using Diener, Emmons, Larsen, and Griffin's (1985) scale so as to be able to control for happiness and establish whether the effect of belief in free will would remain significant.

\section{Present Investigation}

The present investigation focused on the implications of variations in personal philosophies of freedom of will, with the expectation that belief in free will would translate into better 
job performance. We tested the hypothesis with two different samples and methods. Study 1 used a sample that was mainly young, White, female college students. For them, the main career work lay in the future, so workplace performance was measured by means of questions about how they expected to perform in future jobs. We also measured locus of control and Big Five traits in Study 1 to assess the effects of free will beliefs independent of these related constructs. We were particularly interested in discovering whether belief in free will would predict expected job performance above and beyond locus of control.

Study 2, in contrast, drew its sample from a temporary employment center and obtained supervisor ratings of actual job performance. The primary goal was to go beyond selfreports of job performance variables and test our hypotheses with objective job outcome data. The sample itself was older, predominantly Black, and decidedly nonstudent. A second objective of Study 2 was to control for several constructs not measured in Study 1, such as Protestant work ethic. Given this sharp divergence in method and sample, any convergence of evidence would be persuasive.

In both studies, belief in free will was measured rather than manipulated. Both studies used the scale developed by Paulhus and Margesson (1994) specifically to assess differences in personal belief in determinism versus free will.

\section{Study I}

\section{Participants and Procedure}

Participants were 143 undergraduates (113 women) who participated in exchange for partial course credit. Mean age was 20 years old $(S D=1.58)$. In all, $75 \%$ were White, $13 \%$ were Black, and the remainder were of other races or multiple races. Also, $12 \%$ reported Hispanic ethnicity. Materials were administered online at a time of participants' choosing.

\section{Independent Variables}

Belief in free will. Participants completed the seven-item Free Will subscale of the Free Will and Determinism Scale to measure belief in free will (Paulhus \& Margesson, 1994). Items include, "Strength of mind can always overcome the body's desires," "People can overcome any obstacles if they truly want to," and the reverse-scored item, "People do not choose to be in the situations they end up in-it just happens." Participants indicated agreement with these statements on a 5 -point Likert-type scale $(1=$ not at all, $5=$ very much $)$, with higher scores representing stronger beliefs in free will.

Big Five. We used the Ten-Item Personality Inventory (Gosling, Rentfrow, \& Swann, 2003), to measure Big Five traits. Participants rated items according to how well the traits fit them, from 1 (disagree strongly) to 7 (agree strongly).
Intelligence. Participants reported their SAT scores, which served as a proxy for intelligence.

Locus of control. Participants completed the internality dimension of Levenson's (1974) Locus of Control Scale. Example items indicating an internal locus of control include, "Whether or not I get into a car accident depends mostly on how good a driver I am" and "How many friends I have depends on how nice a person I am," scored from 1 (disagree strongly) to 7 (agree strongly).

\section{Dependent Variable}

Participants completed an eight-item measure of expected career performance. Items included, "I will be a success in the workplace," "Career success is important to me," and the reverse-scored item, "Whoever hires me will regret it." Participants rated agreement from 1 (strongly disagree) to 7 (strongly agree). The alpha coefficient was .89.

\section{Results and Discussion}

Several variables were related to expected job performance. As expected, there was a positive association between expected job outcomes and belief in free will $(r=.33, p<.001)$. In addition, locus of control $(r=.26, p=.002)$ and the Big Five dimensions of conscientiousness $(r=.43, p<.001)$ and agreeableness $(r=.28, p=.001)$ were also correlated with expected job performance. In contrast, extraversion $(r=.13, p=.13)$ and emotional stability $(r=.13, p=.12)$ did not correlate with expected job performance, nor did SAT scores $(r=.06$, $p=.50$; see Table 1$)$.

Next, we sought to determine whether belief in free will was an independent predictor of job performance, particularly whether belief in free will would predict job performance above and beyond locus of control. We conducted a hierarchical multiple regression on expected job performance in which SAT scores, locus of control, and the five personality dimensions were entered in the first step; in the second step, we added belief in free will. The addition of belief in free will significantly improved the model, $\Delta R^{2}$ $=.05, F(1,120)=7.83, p=.006$. We repeated the previous analysis for locus of control; in the first step we entered all the variables except locus of control (including free will belief), and we entered locus of control in the second step. Results indicate that the addition of locus of control did not improve the model, $\Delta R^{2}=.009, F(1$, $120)=1.64, p=.20$.

Belief in free will was both a strong and an independent predictor of expected job performance. It accounted for variance beyond that accounted for by locus of control, whereas locus of control failed to account for a significant amount of variance beyond belief in free will. 
Table I. Correlations, Means, and Standard Deviations Among Independent and Dependent Variables for Study I

\begin{tabular}{|c|c|c|c|c|c|c|c|c|c|}
\hline & $\begin{array}{l}\text { Free } \\
\text { Will } \\
\text { Belief }\end{array}$ & Openness & Conscientiousness & Extraversion & Agreeableness & $\begin{array}{l}\text { Emotional } \\
\text { Stability }\end{array}$ & Intelligence & $\begin{array}{l}\text { Locus of } \\
\text { Control }\end{array}$ & $\begin{array}{l}\text { Expected } \\
\text { Career } \\
\text { Performance }\end{array}$ \\
\hline$S D$ & 3.15 & 1.94 & 1.89 & 2.49 & 2.17 & 2.29 & 122 & 6.64 & 5.38 \\
\hline Free will belief & & $.17^{*}$ & $.25 * *$ & .03 & .07 & $.2 I^{*}$ & -.09 & $.23 * *$ & $.33 * *$ \\
\hline Openness & & & $.22 *$ & $.28 * *$ & $.22 *$ & $.42^{* *}$ & .09 & $.20 *$ & $.19 *$ \\
\hline Agreeableness & & & & & & $.23 *$ & -.04 & .09 & $.28 * *$ \\
\hline Emotional stability & & & & & & & .07 & .11 & .13 \\
\hline Intelligence & & & & & & & & .03 & .06 \\
\hline Locus of control & & & & & & & & & $.26 * *$ \\
\hline
\end{tabular}

Note: Free will belief is measured by the Paulhus and Margesson (1994) Free Will subscale.

$* p<.05 . * * p<.01$.

\section{Study 2}

Study 2 extends the results of Study 1 in three ways. First, we assessed employees, rather than students. Second, we measured actual job performance rather than anticipated job performance. Third, we included several variables not measured in Study 1 that could plausibly account for a relationship between belief in free will and job performance.

We tested our hypothesis with people working in a particularly challenging workplace environment, namely, a day labor employment agency. People who work as day laborers are often sent to different places to do different jobs on different days. People who are able to find good, steady jobs may be unlikely to work at day labor agencies. Under such conditions of instability, especially given the lack of the stabilizing influence of ongoing relationships to a particular set of tasks, people, and institutions, impulsive action tendencies may be especially tempting and especially problematic. We note that, unlike participants in Study 1, most of these participants' ideas about free will presumably have not benefited from university instruction on philosophy. Thus, we hoped to assess naturally occurring lay conceptions of free will.

For Study 2, we sought to get actual job performance data rather than have people predict their own future success. Workers were rated by their supervisor with regard to workplace performance, reliability, and other factors. This approach is a stronger and more stringent test than in Study 1, where selfreports of both free will beliefs and expected job outcomes may perhaps have been correlated because of a methodological artifact pertaining to the measurement of internal beliefs. We thought not and in Study 2 measured objective outcomes to provide potentially strong convergent evidence for the effects of Study 1.

Study 2 included measures that were not included in Study 1 but that may have accounted for an effect of belief in free will. The Protestant work ethic extols the value of hard work (and work success) as an indicator, if not a cause, of spiritual merit. We also included a life satisfaction measure, which reflects an overall positive attitude that life is good. We included this scale based on the possibility that disbelief in free will stems from basic unhappiness with life. The measurement of vitality taps a chronic sense of being energetic that might well contribute to a willingness to expend energy toward doing a good job. Our prediction was that the effects of free will would be independent of these other variables.

\section{Method}

Participants. A total of 65 adults ( 9 females, 53 males, 3 unreported) were recruited from a day labor employment agency. Participants completed questionnaires in exchange for $\$ 3$. Ages ranged from 18 to $65(M=37.93, S D=11.00)$. Of the sample, $79 \%$ were Black, $6 \%$ were White, $3 \%$ were Asian, and $12 \%$ did not report race; also, $6 \%$ identified their ethnicity as Hispanic. Although they agreed to participate in the study, 20 additional participants were not included in the data analysis (hence, there were 85 participants originally) because of an apparent inability to read English $(n=2)$, because of a failure to complete major portions of the questionnaire $(n=6)$, or because management did not have sufficient familiarity with the participant to make an informed evaluation $(n=12)$.

Procedure. Working in conjunction with a day labor staffing agency, we invited prospective laborers to complete some questionnaires. We explicitly stated that responses would be confidential to reduce socially desirable responding. Those who agreed to participate gave informed consent and then responded to the questionnaires while waiting to be assigned work for the day. All participants who returned any portion of the materials were compensated.

\section{Independent Variables}

Belief in free will. Individual differences in belief in free will were assessed with the full Free Will and Determinism Scale (Paulhus \& Margesson, 1994). We summed the items to create 
Table 2. Correlations, Means, and Standard Deviations Among Independent and Dependent Variables for Study 2

\begin{tabular}{|c|c|c|c|c|c|c|c|c|c|c|}
\hline & $\begin{array}{l}\text { Free Will } \\
\text { Belief }\end{array}$ & $\begin{array}{l}\text { Life } \\
\text { Satisfaction }\end{array}$ & $\begin{array}{l}\text { Protestant Work } \\
\text { Ethic }\end{array}$ & Vitality & $\begin{array}{l}\text { Work } \\
\text { Effort }^{\mathrm{a}}\end{array}$ & Reliability $^{\mathrm{a}}$ & Consistency $^{a}$ & $\begin{array}{l}\text { Social } \\
\text { Impact }^{\mathrm{a}}\end{array}$ & General $^{a}$ & Overall $^{\mathrm{a}}$ \\
\hline$M$ & 79.75 & 21.00 & 48.00 & 31.73 & 5.62 & 5.31 & 5.00 & 5.65 & 5.09 & 26.66 \\
\hline $\begin{array}{l}\text { Free will } \\
\text { belief }\end{array}$ & & $.32 *$ & .17 & .05 & $.33 * *$ & .18 & $.27^{*}$ & $.35 * *$ & $.30 *$ & $.30 *$ \\
\hline $\begin{array}{l}\text { Life } \\
\text { satisfaction }\end{array}$ & & & .18 & .26 & -.08 & .07 & .04 & .00 & .08 & .03 \\
\hline Vitality & & & & & -.11 & -.07 & -.01 & .06 & -.07 & -.05 \\
\hline Work effort ${ }^{a}$ & & & & & & $.75^{* *}$ & $.8 I^{* *}$ & $.78^{* *}$ & $.88 * *$ & $.90 * *$ \\
\hline Reliability $^{\mathrm{a}}$ & & & & & & & $.93 * *$ & $.78 * *$ & $.90 * *$ & $.94 * *$ \\
\hline Consistency $^{\mathrm{a}}$ & & & & & & & & $.78^{* *}$ & $.94 * *$ & $.96 * *$ \\
\hline Personality ${ }^{a}$ & & & & & & & & & $.82 * *$ & $.88^{* * *}$ \\
\hline
\end{tabular}

Note: Free will belief measured by full Paulhus and Margesson (1994) Free Will and Determinism Scale.

${ }^{a}$ Measure of job performance.

$* p<.05 . * * p<.01$.

an index of belief in free will, with higher scores representing stronger beliefs in free will.

Vitality. We assessed how energetic participants felt using the Vitality Scale (Ryan \& Frederick, 1997). This scale consists of seven items, such as, "I have energy and spirit" and "I nearly always feel alert and awake." Participants rated their agreement on a scale from 1 (not at all true) to 7 (very true).

Protestant work ethic. We used the Protestant Ethic Scale (Mirels \& Garrett, 1971) to assess the extent to which individuals value work. Items such as, "There are few things as satisfying as doing one's best" and "Any person who is able and willing to work hard has a good chance of succeeding," were rated by participants on a scale from 1 (strongly disagree) to 7 (strongly agree). Because of time constraints, we shortened the scale to 10 items.

Satisfaction with life. Participants' satisfaction with life as a whole - rather than satisfaction with individual domains such as health or finances - was assessed using the Satisfaction with Life Scale (Diener et al., 1985). Participants rated five items such as, "The conditions for my life are excellent" and "If I could live my life over, I would change almost nothing," on a scale from 1 (strongly disagree) to 7 (strongly agree).

Dependent Variable. Five dimensions of workplace performance were assessed by a direct supervisor. Individuals were rated from 1 (low) to 7 (high) on work effort (as defined as "the amount of effort put into tasks"), reliability ("frequency of doing what is asked"), consistency ("regularity of showing up for day labor"), positive social impact ("degree of positive impact on fellow employees"), and general assessment ("general workplace performance"). Interitem correlations ranged from .75 to $.94(M=.84)$, suggesting that these dimensions were independent but interrelated. We summed these items to create a composite measure of overall job performance $(\alpha=.96)$.

\section{Results and Discussion}

The relationship between belief in free will and overall job performance was significant $(r=.30, p=.014)$. In addition, belief in free will was positively correlated with four of the five measures of workplace performance (see Table 2): work effort ( $r=$ $.33, p=.008)$, consistency $(r=.27, p=.03)$, positive social impact, $(r=.35, p=.005)$, and general assessment $(r=.30$, $p=.016)$. The relationship between belief in free will and reliability fell short of significance $(r=.18, p=.15)$. No other independent variable predicted any job performance measure $(r$ values $<.19$ ), though this could be partially because of the small sample size.

We included all independent variables in a stepwise multiple regression to determine their relative impact on overall job performance. The only significant predictor to emerge was belief in free will $\left(\beta=.36, t=2.79, p=.007, R^{2}=.13\right)$. Life satisfaction, work ethic, and personal energy were unrelated to overall job performance $(t$ values $<1)$. Next, we conducted a hierarchical multiple regression on overall job performance in which the three variables other than free will were entered in the first step; in the second step we added free will. Results showed that adding belief in free will significantly improved the model, $\Delta R^{2}=$ $.12, F(1,51)=7.09, p=.01$. Thus, the effect of free will on job performance had an effect over and above that of the other tested variables and was not contingent on the other variables.

\section{General Discussion}

The present investigation found support for the hypothesis that stronger belief in free will predicts better job performance. The 
current study relied on naturally occurring individual differences in the belief of freedom of the will rather than manipulating belief in free will. It is the first study in our search of the literature that has found practical benefits to a personal philosophy of believing that one has free will.

We anticipated this finding on the basis of emerging research demonstrating that the effortful control of one's impulses requires the exertion of a psychological resource (willpower; Baumeister, Bratslavsky, Muraven, \& Tice, 1998), which is dependent on a biological resource (glucose; Gailliot et al., 2007; Masicampo \& Baumeister, 2008), and disbelief in free will serves as a cue not to bother exerting effortful control (Baumeister et al., 2009; Vohs \& Schooler, 2008). Thus, those who espouse a personal philosophy that human action is freely chosen seem willing to expend the resources necessary for controlled regulation of behavior, which is vital for successful work. Disbelief in free will, in contrast, apparently fosters a rather impulsive style of action control that undermines effective work.

The present research contributes to an understanding of executive function. The executive function aspect of the self is responsible for one's actions, as distinct from the other two main dimensions: self-knowledge and the interpersonal self. Executive function is based on choosing and exerting control over oneself and one's environment and forms the basis of the human action control system. One way of interpreting the current findings is that believing in free will enhances executive function, whereas disbelief in free will undermines it.

Belief in free will predicted anticipated job performance above and beyond contentiousness, suggesting that belief in free will is both a robust and an independent predictor of job performance. The strength of the relationship between conscientiousness and anticipated job performance in Study $1(r$ $=.43$ ) was at least on par with previous findings for conscientiousness ( $r=.30$; Barrick \& Mount, 1991; Tett et al., 1991). That belief in free will predicted anticipated career success independent of conscientiousness is especially noteworthy given that conscientiousness outweighs other personality dimensions so routinely in predicting job performance that it has been called the "Big One" (Schmidt \& Hunter, 1992).

We also replicated the finding that the more internal one's locus of control of reinforcement, the better one's job performance. The strength of the relationship we observed $(r=$ .26) was also comparable with previous findings $(r=.22$; Judge \& Bono, 2001). There is some conceptual overlap between belief in free will and locus of control, so one important test of the utility of belief in free will as a predictor of job performance was whether it would predict job performance above and beyond locus of control. Results indicated that, as expected, the two constructs are independent and that belief in free will outperformed locus of control as a predictor of expected job performance.

Study 2 ruled out several additional alternative explanations. For instance, it is plausible that the relationship between belief in free will and job performance could be explained by Protestant work ethic (or life satisfaction or feeling energetic), but this was not the case. Furthermore, our design in Study 2 sought to minimize self-presentational and self-report biases by having job performance independently evaluated by a supervisor familiar with each individual's work.

Protestant work ethic was not a strong predictor of work performance in the current study, although it has been in previous work (e.g., Furnham, 1990). Protestant work ethic is worth mentioning because it was heavily influenced by Calvinism, which holds that whether one receives God's grace has already been determined. People with this worldview are motivated to work hard to persuade themselves and others that they are among the recipients of God's favor. Thus, some varieties of determinism may also prompt hard work.

The populations from which participants were drawn varied greatly in the two studies. In Study 1, they were primarily young, female, and White. They were also college students, suggesting a relatively high socioeconomic status (SES). In Study 2, participants were somewhat older and mainly Black and male. Their employment as day laborers suggests relatively low SES. Finding similar results across groups with very little in common suggests the results may be broadly generalizable.

\section{Limitations and Future Directions}

One limitation of the present work is that in Study 1 we used self-reports (though this was not the case in Study 2). A second limitation is that the sample size in Study 2 was small (though this was not the case for Study 1). We also did not manipulate belief in free will experimentally, so we cannot rule out the possibility that good job performance causes belief in free will. Future work may consider experimental studies in which free will beliefs are altered experimentally, with the expectation that this would lead to a changes in job performance.

\section{Conclusions}

Free will is a concept debated by philosophers and with relevance for people's daily lives. Laypersons differ in the extent to which they perceive themselves as having freedom of action. These differences in personal philosophy have implications: Those who believe in free will demonstrate better workplace performance than those who do not. We interpret this finding in the context of emerging research on manipulated states of enhanced or deflated free will beliefs (Baumeister et al., 2009; Vohs \& Schooler, 2008) and conclude that belief in free will facilitates controlled behavior and buffers against impulsive action, which, in turn, translates to better job performance.

\section{Acknowledgments}

We thank Ben Dougherty and Keri Meyer for assistance with data collection (Study 2).

\section{Declaration of Conflicting Interests}

The authors declared no potential conflicts of interest with respect to the authorship and/or publication of this article. 


\section{Financial Disclosure/Funding}

The authors disclosed receipt of the following financial support for the research and/or authorship of this article: Preparation of this manuscript was facilitated by a grant from the Templeton Foundation.

\section{References}

Barrick, M. R., \& Mount, M. K. (1991). The Big Five personality dimensions and job performance: A meta-analysis. Personnel Psychology, 44, 1-26.

Baumeister, R. F., Bratslavsky, E., Muraven, M., \& Tice, D. M. (1998). Ego depletion: Is the active self a limited resource? Journal of Personality and Social Psychology, 74, 1252-1265.

Baumeister, R. F., Masicampo, E. J., \& DeWall, C. N. (2009). Prosocial benefits of feeling free: Disbelief in free will increases aggression and reduces helpfulness. Personality and Social Psychology Bulletin, 35, 260-268.

Baumeister, R. F., Vohs, K. D., \& Tice, D. M. (2007). The strength model of self-control. Current Directions in Psychological Science, 16, 396-403.

Brown, K. G., Le, H., \& Schmidt, F. L. (2006). Specific aptitude theory revisited: Is there incremental validity for training performance? International Journal of Selection and Assessment, 14, 87-100.

Diener, E., Emmons, R. A., Larsen, R. J., \& Griffin, S. (1985). The Satisfaction with Life Scale. Journal of Personality Assessment, 49, 71-75.

Furnham, A. (1990). A content, correlational, and factor analytic study of seven questionnaire measures of the Protestant work ethic. Human Relations, 43, 383-399.

Gailliot, M. T., Baumeister, R. F., DeWall, C. N., Maner, J. K., Plant, E. A., Tice, D. M., et al. (2007). Self-control relies on glucose as a limited energy source: Willpower is more than a metaphor. Journal of Personality and Social Psychology, 92, 325-336.

Gosling, S. D., Rentfrow, P. J., \& Swann, W. B. (2003). A very brief measure of the Big-Five personality domains. Journal of Research in Personality, 37, 504-528.

Hunter, J. E. (1983). The prediction of job performance in the military using ability composites: The dominance of general cognitive ability over specific attitudes (Department of Defense Contract F41689-83-C-0025). Chandler, AZ: Research Applications.

Judge, T. A. (2009). Core self-evaluations and work success. Current Directions in Psychological Science, 18, 58-62.

Judge, T. A., \& Bono, J. E. (2001). Relationship of core self-evaluations traits - self esteem, generalized self-efficacy, locus of control, and emotional stability - with job satisfaction and job performance: A meta-analysis. Journal of Applied Psychology, 86, 80-92.

Judge, T. A., \& Hurst, C. (2007). The benefits and possible costs of positive core self-evaluations: A review and agenda for future research. In D. Nelson \& C. L. Cooper (Eds.), Positive organizational behavior (pp. 159-174). London: Sage.

Kane, R. (2002). Oxford handbook of free will. New York: Oxford University Press.

Levenson, H. (1974). Activism and powerful others: Distinctions within the concept of internal-external control. Journal of Personality Assessment, 38, 377-383.
Masicampo, E. J., \& Baumeister, R. F. (2008). Toward a physiology of dual-process reasoning and judgment: Lemonade, willpower, and expensive rule-based analysis. Psychological Science, 19, 255-260.

McClelland, D. C. (1961). The achieving society. New York: Van Nostrand.

Mirels, H., \& Garrett, J. (1971). The Protestant ethic as a personality variable. Journal of Consulting and Clinical Psychology, 36, 40-44.

Mount, M. K., Oh, I., \& Burns, M. (2008). Incremental validity of perceptual speed and accuracy over general mental ability. Personnel Psychology, 61, 113-139.

Paulhus, D. L., \& Margesson, A. (1994). Free Will and Determinism (FAD) Scale. Unpublished manuscript, University of British Columbia, Vancouver, Canada.

Rotter, J. (1966). Generalized expectancies for internal versus external control of reinforcements. Psychological Monographs, 80, 609.

Ryan, R. M., \& Frederick, C. M. (1997). On energy, personality and health: Subjective vitality as a dynamic reflection of well-being. Journal of Personality, 65, 529-565.

Schmidt, F. L., \& Hunter, J. E. (1992). Development of a causal model of processes determining job performance. Current Directions in Psychological Science, 1, 89-92.

Schmidt, F. L., \& Hunter, J. E. (2004). General mental ability in the world of work: Occupational attainment and job performance. Journal of Personality and Social Psychology, 86, 162-173.

Spector, P. E. (1982). Behavior in organizations as a function of employees' locus of control. Psychological Bulletin, 91, 482-497.

Tett, R. P., Jackson, D. N., \& Rothstein, M. (1991). Personality measures as predictors of job performance: A meta-analytic review. Personnel Psychology, 44, 703-742.

Thomas, W. H. N. G., Sorensen, K. L., \& Eby, L. T. (2006). Locus of control at work: A meta-analysis. Journal of Organizational Behavior, 27, 1057-1087.

Vohs, K. D., Baumeister, R. F., Schmeichel, B. J., Twenge, J. M., Nelson, N. M., \& Tice, D. M. (2008). Making choices impairs subsequent self-control: A limited resource account of decision making, self-regulation, and active initiative. Journal of Personality and Social Psychology, 94, 883-898.

Vohs, K. D., \& Schooler, J. (2008). The value of believing in free will: Encouraging a belief in determinism increases cheating. Psychological Science, 19, 49-54.

Vroom, V. H. (1964). Work and motivation. New York: John Wiley. Weber, M. (1905). Die protestantische Ethik und der "Geist" des Kapitalismus [The Protestant ethic and the sprit of capitalism]. Archiv für Sozialwissenschaft und Sozialpolitik, 20, 1-54.

\section{Bios}

Tyler Stillman is a postdoctoral researcher at Florida State University.

Roy F. Baumeister is a social psychologist who has worked very hard with or without free will.

Kathleen D. Vohs is the University of Minnesota McKnight LandGrant Professor, McKnight Presidential Fellow, and Associate 
Professor of Marketing, Carlson School of Management, University of Minnesota.

Nathaniel M. Lambert is completing his $\mathrm{PhD}$ at Florida State University.
Frank D. Fincham is Eminent Scholar and Director of the Florida State University Family Institute.

Lauren Brewer is a graduate student in social psychology at Florida State University. 